【論文】

\title{
スムーズブラスティングの機構に関する実験的検討 \\ SOME CONSIDERATIONS ON THE MECHANISM OF SMOOTH-BLASTING
}

\author{
中 川浩 二*・坂 本 伦** . 山本顕 一 郎***
}

By Koji NAKAGAWA, Takeshi SAKAMOTO and Ken-ichiro YAMAMOTO

\section{1.はじめに}

地下発電所の建設, 地下岩盤内貯油施設の計画, ある いはトンネル掘削に㧍ける NATM の一般化により制 御発破の重要性が最近見直され, かつ論じられるように なってきている.しかしながら制御発破の機構はその重 要性, 施工の頻度にもかかわらず必ずしも明らかではな く, 実際の施工においては多く経験に基づいた方法がと られているようである。

制御発破（以下，スムーズブラスティング：SB とよ ぶ）については種々の方法がある11 がラインドリリング を除いていずれも爆破により爆破孔，あるいは爆破孔に 対して補助的に設けられた空孔を連結させる方法であり 対その目的は一つには不必要な破壞を岩盤内に生じせし めないことであり，また一つにはできるだけ滑らかな岩 盤壁面を作ることである.SB の機構，すなわち爆破孔 が連結する機構に関しては爆破による衝撃波の重ね合わ せによるとする説，衝撃波により隣接孔壁の孔間を結ぶ 方向にクラックが発生することによるとする説，あるい は準静的なガス圧によるとする説などがあるが必ずしも 定説をみないようである21.

$\mathrm{SB}$ の機構が明確にされていない理由の一つとして, $\mathrm{SB}$ が実際には岩盤を対象として行われるものであると いうことを挙げることができよう．岩盤は通常多くの節 理，層理を含み，また岩質そのものも多種多様であり， 実際上一様な状態証存しないといえる.さらに岩盤の 破壊は節理，層理の影響を非常に大きく受けるため, $\mathrm{SB}$ 技術の比較が困難となり, 理論的解明も容易ではな いであろらと思われる。

本研究では実際の岩盤と比較して十分に均質であるセ

* 正会員 工博 山口大学助教授 工学部土木工学科

** 日本化薬 (株) 火薬事業部 業務課長

*** 日本化薬 (株) 火薬研究所 研究課長
メントモルタルを用いてモデル供試体を作製し，これに より SB の機構に大きな影響をもつと思われる隣接孔間 の爆破時間差についての検討を行い，かつそれをもとに SB の機構についての考え方に関する考察を行ったので これを報告する.

\section{SB の機構に関する検討}

$\mathrm{SB}$ の機構に関しては諸説あり，はっきりとした定説 は現在もなお明確にはされていないようである.ここで はSB の機構についての従来の考え方について述べ，さ らに筆者らの一つの考え方を提案する.

\section{（1） SB の機構に関する従来の考え方}

a） 衝撃波の重祆合わせによるとする説

これについては Paine ら ${ }^{3}$ により述べられており, 基 本的には爆破により発生する衝撃波が隣り合う爆破孔間 で重叔合わせられ，爆破孔間を結ぶ面上で引張応力が大 きくなり，両孔を結ぶ破断面が形成されるとする考え方 である.この説の説明としてはベンチカットの整列発破 などで各孔を単独で爆破した場合には爆破面には激しい 凹凸が生じるが，斉発，あるいは段差の小さい MS 雷 管などで各孔を起爆すると爆破面が一様となることをう まく説明できるなどといわれている．しかしこの考え方 では爆破孔から伝播する衝撃波の波頭部分の重称合わせ が破壊の発生の原因であるとしているところに問題があ る.すなわち, 通常のトンネル発破の SB の場合のよう に孔間隔が $60 \mathrm{~cm}$ 程度であるとき, 岩盤中を伝わる弾性 波の伝播速度を $4000 \mathrm{~m} / \mathrm{s}$ として, この間を弾性波が伝 播するのに必要な時間は $0.15 \mathrm{~ms}$ となる. 通常の $\mathrm{SB}$ で は起爆は段数の大きい MS あるいは DS 雷管の用いら れることが多く, これら雷管間の起爆時間差は $0.15 \mathrm{~ms}$ と比べて十分に大きくなり得ると考えられるため,この 説による解勫はあまり現実的ではないであろう。しかし 
$\mathrm{SB}$ 用の各爆破孔を導爆線でつないだり，あるいは雷管 の起爆方法を工夫するなどして起爆時間差を小さくする ことは技術的に可能であり，考察する意味はあるであろ 5 .

b）衝撃波による隣接孔周縁の応力集中に伴うクラッ クの発生を考える説

伊藤ら ${ }^{4)}$ は一孔の爆破によって生じる衝撃波が隣接孔 を通過するとき，この隣接孔周縁の爆破孔を結ぶ面上に 大きな応力集中を生じ，この部分にクラックを発生させ ると考えた. そしてクラックの発生した孔が続いて爆破 されるとき，この孔は切り欠きを有する爆破孔として作 用し, 爆破により既存のクラックをその方向に大きく伸 展させ, かつそれ以外の方向のクラックの発達を抑制す る効果があるとしている.

c） 準静的なガス圧によるとする考え方

SB 結果に準静的なガス圧が及ぼす影響が大であると する考え方 5) はかなり一般的である.このことは石材の 採掘に㧍いて衝撃的応力波のほとんどない黒色火薬が用 いられてきたことから容易に想像し得るところである.

すなわち，この場合には破壊の開始に衝撃波の助けはな い.そして隣り合う孔のガス圧による応力場の重衫合わ せの結果として準静的な孔周縁の応力集中によりクラッ クが発生し, 主応力方向に沿った破断面を形成すると考 えることになる.しかし，実際のSBにおいては猛度の 高い爆薬を用いることが多いため, たとえデカップリン グ係数を大きくとっても圧力のピーク值までの立ち上が り時間海短く, 衝撃的な応力波が発生するため, 準静的 ガス圧のみを考えることは一般的ではない。

\section{（2）爆破孔間のクラックがガス圧による応力場にお いて選択的に発達させられるとする考え方}

前の a)，b）説では爆破により発生した衝撃波が伝播 し, 孔間あるいは隣接孔周縁に孔間を結ぶ方向のクラッ クを発生し，それが SB を支配する要因になると考えて いる.これに対し筆者らは一つの考え方を提案する.す なわち爆破衝撃波により爆破孔周辺に多数の放射状クラ ックが発生し, これがガス圧の作用により発達する過程 で隣接孔のガス圧等の影響を受け，孔間を結ぶ方向にあ るクラックが選択的に発達させられると考えるものであ る.

SB においては一孔の爆破に続いて隣接する孔の爆破 が短い時間間隔で行われる.すなわち, 最初の爆破の行 われた孔からの衝撃波の波頭部分は過ぎ去ってもそれに 続く準静的なガス圧による応力場が作用し，そこへ隣接 孔の爆破が行われ，これによる応力場が生じる. そして 両者の重社合わせにより両孔を結ぶ面に近いところでは 引張応力は大きく, その他の方向では小さくあるいはと
きに圧縮応力状態となる. 後に示す 写真一1 亿みられる ように爆破孔周辺には多数の放射状クラックが生じる. そして準静的なガス圧の作用によってこれらの放射状ク ラックのあるもの娍長させられることとなるが, この 過程で隣接する孔の爆破衝撃波のため, 両孔を結ぶ面近 くのクラックが特に成長させられる.また遅れて爆破さ れた孔の周囲で洗の孔の爆破によるガス圧の応力場で 爆破が行われるためやはりクラックの成長が選択的とな る.このようにして爆破孔から発達するクラックは, 両 孔を結ぶ面の近くで特に発達する結果になると考えられ る.

ところで爆破により孔壁に作用する衝撃は著しく大き いため，特に孔間隔が大きい場合には隣接孔相互の影響 を受けずに任意の方向にいくつかのクラックが成長し得 る、ところがそれぞれの孔の爆破による応力場はそれぞ れの孔に対して軸対称となり，2つの孔の影響を受ける 応力場では最小主応力方向（引張応力に直交する方向； クラックの発生する可能性の高い方向）注滑らかな曲線 で両孔を結ぶことになる，応力場において発達するクラ ックはこの方向に平行な方向をとろらとする．そのため 任意方向に発生したクラックも両孔を結ぶ面に近いもの はこの方向に沿って発達し, それ以外のものは発達が抑 えられることになる.この状況は隣接孔の爆破が同時に 行われるとき，両孔を結ぶ面から離れてクラックが発生 する場合にも同様となることはいうまでもない.

\section{3. 実験の目的と方法}

前述の上うに SB の機構に関して種々の考え方が可能 であり，爆破条件によってはいずれの説も可能性がある ように思われる.そして実際の SBにおいてはそれぞれ 独立にではなく，複合的な形で作用するのであろう．

$\mathrm{SB}$ に掞いて隣接爆破孔間の爆破時間のずれを考える とき, 前述の諸説の有効性に差が生じる. 隣接する 2 孔 を完全に同時に爆破すると衝撃波の孔間での重ね合わせ は現実的となり，また同時に準静的なガス圧も両孔で同 様に作用することになる.これに対して隣接する $2 つ の$ 孔の爆破を十分な時間差のもとで行らとき，衝撃波の重 放合わせは当然のこと，準静的なガス圧の相互作用も生 じない.しかし一孔の爆破による衝撃波により隣接孔周 縁にクラックが生じる可能性はあり，この意味での 2. (1) の b) の機構による SB は期待できることになる. 両者の中間程度の適当な時間差, 寸なわち最初の爆破孔 からの衝撃波の波頭は通過したとしても爆破孔中にかな りの準静的なガス圧が作用している状態で次の孔の爆破 が行われる場合には衝撃波波頭部分の重社合わせは期待 できないが衝撃波による隣接孔周縁のクラックの発生お 
よびガス圧による応力場でのクラックの発達による滑ら かな壁面の形成は期待できる.

以上のことを考虑してまず，2.(1)，b）の伊藤らの 考え方の可能性の確認についての予備的実験を行った. そして, 隣接する 2 つの爆破孔を適当な時間間隔で爆破 し，そのときの $\mathrm{SB}$ 結果が爆破時閒差によってどのよう に変わるかを調べ，SB 機構に関して前節で述べた解釈 の合理性を検討することを目的とする実験を行った.

\section{（1）衝撃波による空孔周縁のクラック発生に関する 予備的実験と結果}

実際に衝撃波が爆破孔から伝播するとき，隣接する孔 周辺の孔間を結ぶ方向にクラックが発生し得るものかど うか, またその薬量, 距離とクラックの程度に関しては 資料がない，そこでこの点についての資料を得るための 一つの予備的実験を行った. すなわち, $100 \times 100 \times 3 \mathrm{~cm}$ のセメントモルタル板を作製 し, 板中央に直径 $15 \mathrm{~mm}$ の爆破孔と，その周辺爆破孔からの距離 $25 \sim 42.5 \mathrm{~cm}$ の 位置に, 直径 $20 \mathrm{~mm}$ 抒よび $30 \mathrm{~mm}$ の空孔を $45^{\circ}$ 間隔に 8 個配置した. 空孔の位置は㨁接の爆破衝撃波によるク ラックと，周囲の自由端からの反射引張波によるクラッ クとを分離するため，4本の対称軸から $22.5^{\circ}$ 偏った 位置に配した. 6 号電気雷管の周囲を紙筒に包んだ $6 \mathrm{~g}$ のPETN で巻き, 爆破孔に密装薬状態として爆破し, 発生したクラックをインクでトレースしたものが写真一 1 である.この場合クラックは閉じたクラックとなり， 肉眼での検出は困難となる，そのためアセトンを浸した 脱脂綿で供試体表面を手早くぬぐうことによりその痕跡 を検出した．この空孔周縁から発生するクラックのらち 爆破孔側のクラックの長さを測定し，爆破孔からの距離 に対して示したものが図一1である.

これによると発生するクラック長は爆破孔から空孔ま での距離に依存し，クラック発生の限界が抒よそこの条 件に対して $35 \mathrm{~cm}$ となることが認められた．また薬量 を減じて (3g の PETN で 6 号雷管を巻き, 直径 13 $\mathrm{mm}$ の孔に装填) 爆破した場合にはこの距離はおよそ

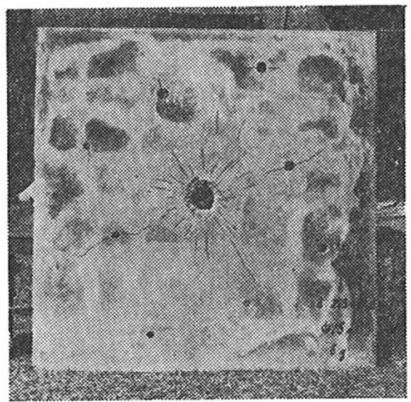

写真一1 爆破孔周辺および隣接孔 周辺でのクラックの発達
$30 \mathrm{~cm}$ となった.こ のことから伊藤らに

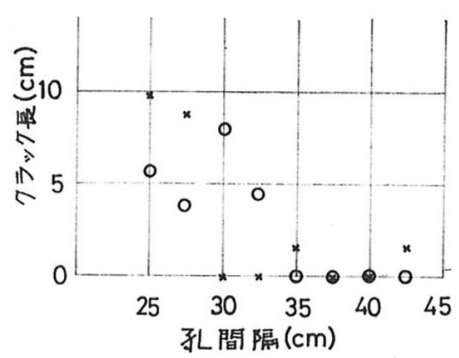

(O : 空孔径 $30 \mathrm{~mm}, \times$ : 空孔涤 $20 \mathrm{~mm}$ )

図一1 爆破孔からの衝撃波による空孔からの クラックの発達

よる説は爆破孔間距離が短いときには十分に可能性があ るが長くなると適切でないと考えられる。

な押, 本実験に用いたモルタル供試体は配合, 養生条 件とも後述の実験 A,B に抢けるものと同じである.

\section{（2） SB 結果に与える隣接孔の爆破時間差の影響に} 関する実験

用いた供試体はいずれもセメントモルタル製であり， 大きさは $57 \times 27 \times 10.5 \mathrm{~cm}$ である. 材料には砕砂と早 強ポルトランドセメントを用い, 配合は重量比で水：セ メント : 砂 $=0.52: 1.0: 2.0$ とした. 練り混ぜ後, 木 製型わくに打設, 1 日で脱型, 実験日まで湿潤状態を保 つようにした，材令はおよそ 2 週間としている.モルタ ル打設時のフロー值は 159 , 材令 2 週間の一軸圧縮強度 は $50.9 \mathrm{MN} / \mathrm{m}^{2}$ であった。

a) 実験 $\mathrm{A}$

実験 $\mathrm{A}$ においては，プリスプリッティングの場合のよ らに自由面を考慮しない状態での爆破を考え，あらかじ め爆破された孔の存在する場へ隣接孔の爆破により両孔 を結ぶ方向に対してある傾きをなしてクラックが発達し てくる場合のクラックの進展と両孔の連結の状態を検討 した. 供試体は平行な 2 本の孔を $S=16 \mathrm{~cm}$ の間隔に有 し，その一方は長さ $15 \mathrm{~mm}$, 幅 $3 \mathrm{~mm}$ の切り欠きをも っている. 切り欠きの方向は他の孔の中心方向に対して $\theta=0^{\circ}, 10^{\circ}, 20^{\circ}$ の傾きをそれぞれもち(図一2 (a)), 爆破 により切り欠き方向へのクラックの発達を卓越させるこ とを目的としている. 実験の手順はまず切り欠きを有さ

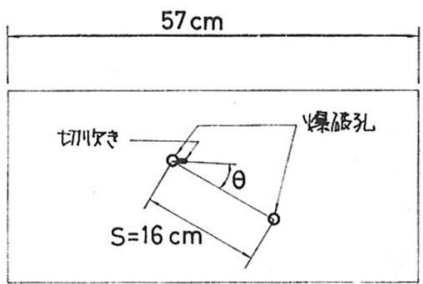

図-2 (a) 実験 $\mathbf{A}$ 用供試体 $\left(\theta=0^{\circ}, 10^{\circ}, 20^{\circ}\right)$

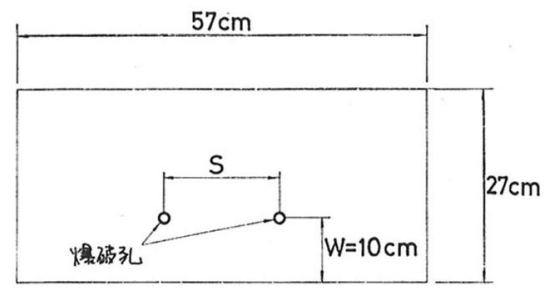

図一2 (b) 実験 B 用供試体 $(S=8,10$, $12,14,16,20,25 \mathrm{~cm})$ 
ない孔の爆破を行い，この爆破孔周辺にクラックを発生 させ，あるいは応力場を作り，その後ある一定の時間間 隔を扔いて切り欠きを有する孔の爆破により切り欠き方 向へのクラックを卓越発達させる. そのときこの遅れて 発達してきたクラックが先の爆破孔とどのような形で連 結されるかを時間差との関係で検討しようとするもので ある。

爆破孔の直径は約 $12.5 \mathrm{~mm}$ であり，爆薬には導爆線 （外径約 $5.2 \mathrm{~mm}$, 心薬は PETN $10.7 \mathrm{~g} / \mathrm{m}$ ) を用い, 導 爆線にテープを 2 か所巻きつけ孔径に近い太さとし, 爆 破時に導爆線が孔のほぼ中央に位置するように努めた． また両孔の爆破時間差は $0,0.5 \mathrm{~ms}, 1.0 \mathrm{~ms}, 20 \mathrm{~ms}$ と し，そのほかに同時爆破および装薬をし直して爆破した ものおよび切り欠きを有する孔のみを爆破したものをと っている.

\section{b) 実験 B}

実験 $\mathrm{B}$ においては $\mathrm{SB}$ によって自由面と平行な破断面 を作ることを目的とし，供試体の一面に対して 2 本の爆 破孔を平行に並べた．最小抵抗線距離 $W=10 \mathrm{~cm}$ に対 して爆破孔閒の距離は $S=8,10,12,14,16,20,25 \mathrm{~cm}$ としている(図一2 (b)). 爆破孔の直径, 爆薬, 爆破時 間差等に関しては実験 $\mathrm{A}$ と同じである。それぞれの爆破 時間差で爆破された供試体に発生, 発達するクラックの 性状から SB の機構に関して前節で述べた解釈を検討す
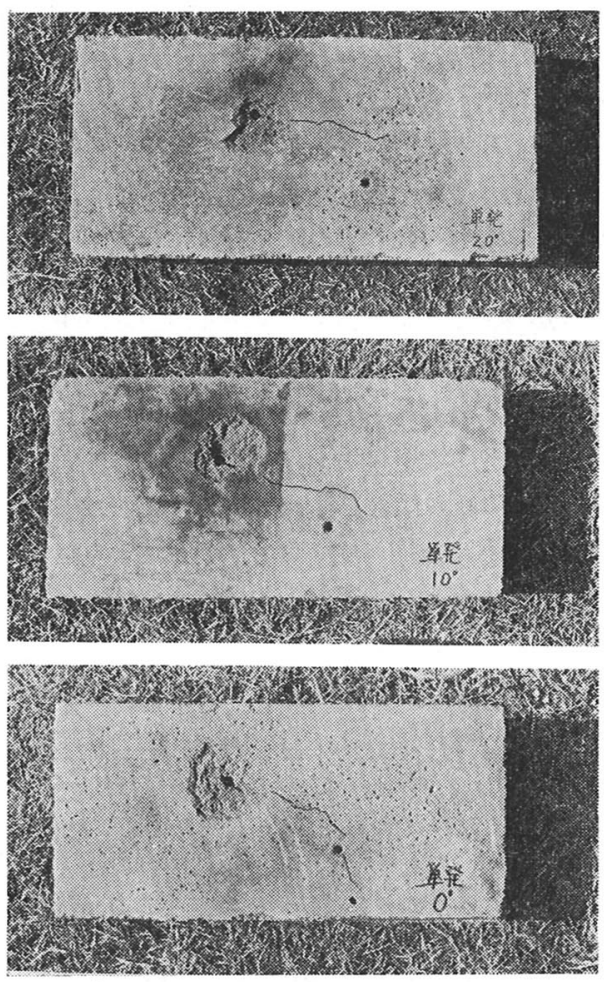

（a）切り欠き孔のみ爆破
るとともに最終壁面の平滑度をその両孔中心間を結ぶ面 から壁面の最大の偏り (Langefors らは Unevenness と 定義している5) として求め，SB に拈ける爆破時間差 の効果について検討した.

なお爆破により供試体が分離飛散するのを防ぐ目的で 実験 A の場合には供試体外周に沿って $6 \mathrm{~mm}$ 丸鋼を二 重に口の字形に配し，また実験 Bの供試体には SB によ る破断面を作る面を除いた 3 面に二重にコの字形に配し た.

爆破時間差は $0,0.5 \mathrm{~ms}, 1.0 \mathrm{~ms}$ の場合は電気雷管 から両爆破孔に至る導爆線の長さを調節することによっ た。すなわち導爆線の爆速はおよそ $7000 \mathrm{~m} / \mathrm{s}$ とほぼ— 定であることから雷管で起爆される位置から両爆破孔に 至るまでの 2 本の導爆線の長さの差を $0,3.5 \mathrm{~m}, 7.0 \mathrm{~m}$ とすることによって導爆線中を伝わる爆蠹伝播時間の差 からほぼ正確な時間差を現出することが可能となる．ま た $20 \mathrm{~ms}$ の時間差については瞬発および 2 段の 2 つの電 気雷管を用いて起爆した。

供試体の表から裹一と貫通して導爆線を配し爆破を行 うとき，表抽よび裏面では back break の状態を生じ， その状況は裹面の方が著しい(ここで表と裹とは爆輩が 表から裏へと進行するとして定義する)．以下に示す資 料はすべて back break の小さい表側の面についてのも のである.
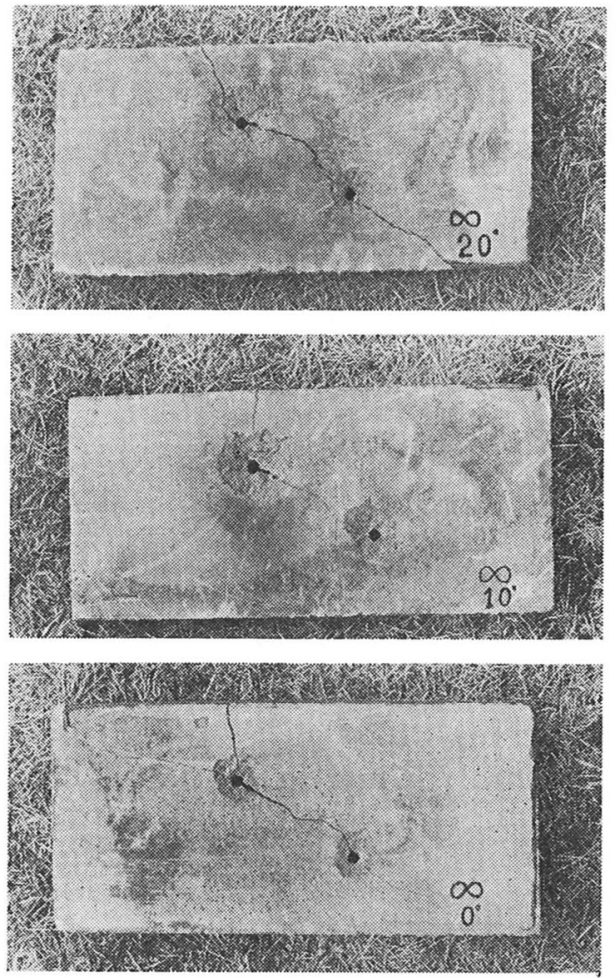

（b）右下孔爆破後，左上孔を装薬し直して袢破 

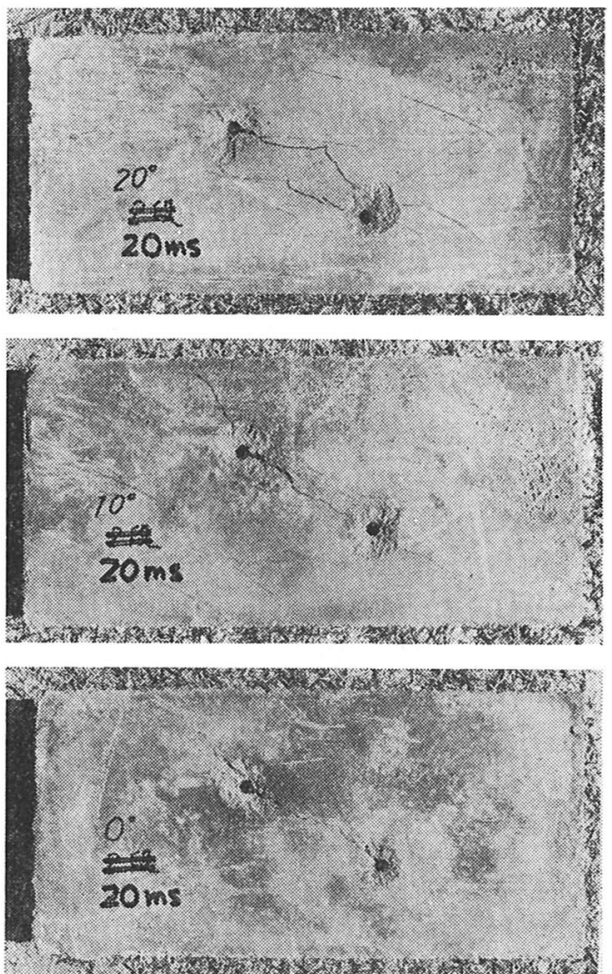

（c）右下孔爆破後, 左上孔爆破までの時間差 $20 \mathrm{~ms}$
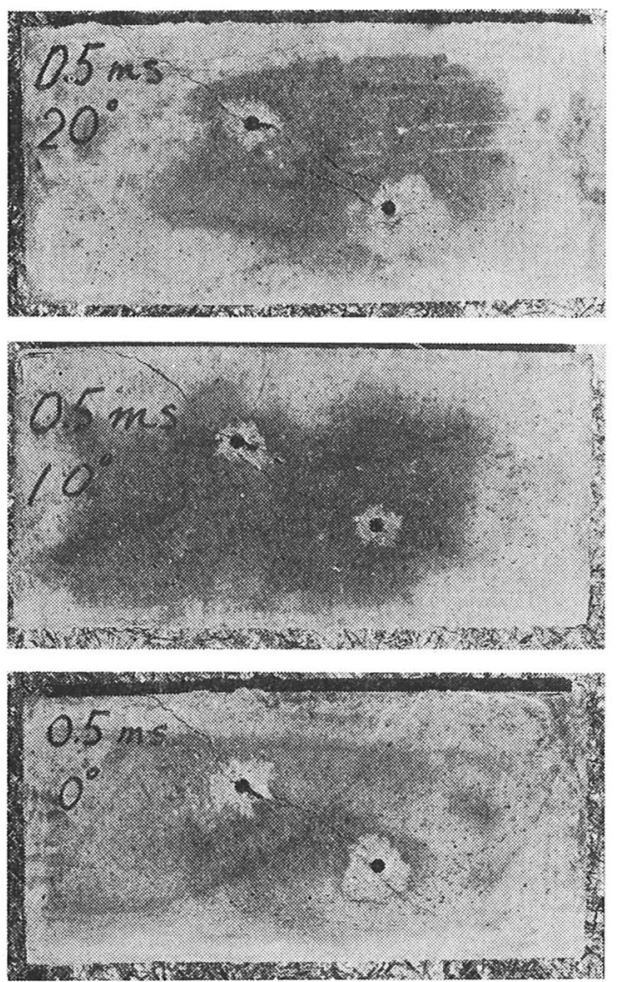

(e) 右下孔爆破後, 左上孔爆破むでの時間差 $0.5 \mathrm{~ms}$
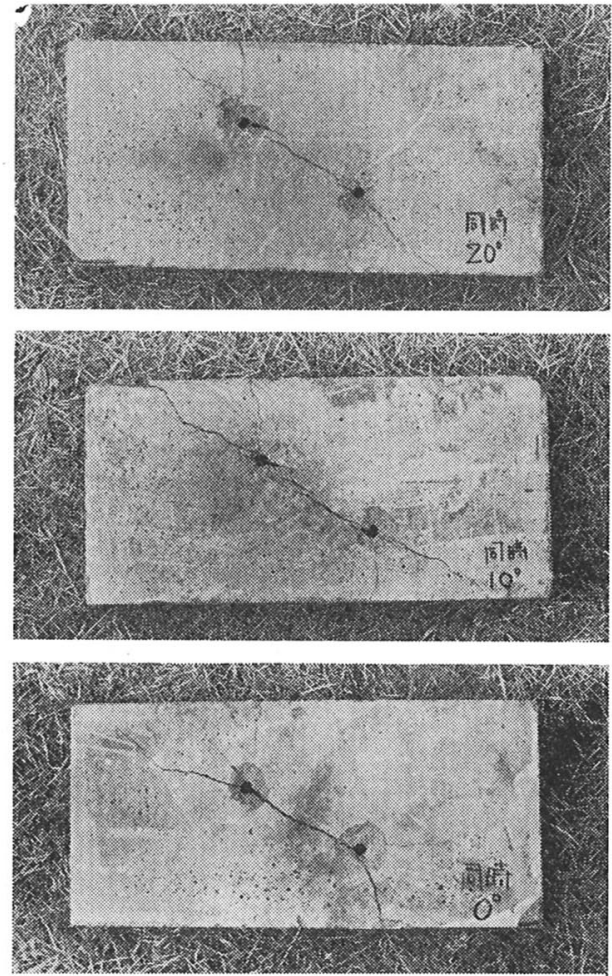

（d）右下孔爆破後, 左上孔爆破までの時間差 $0 \mathrm{~ms}$
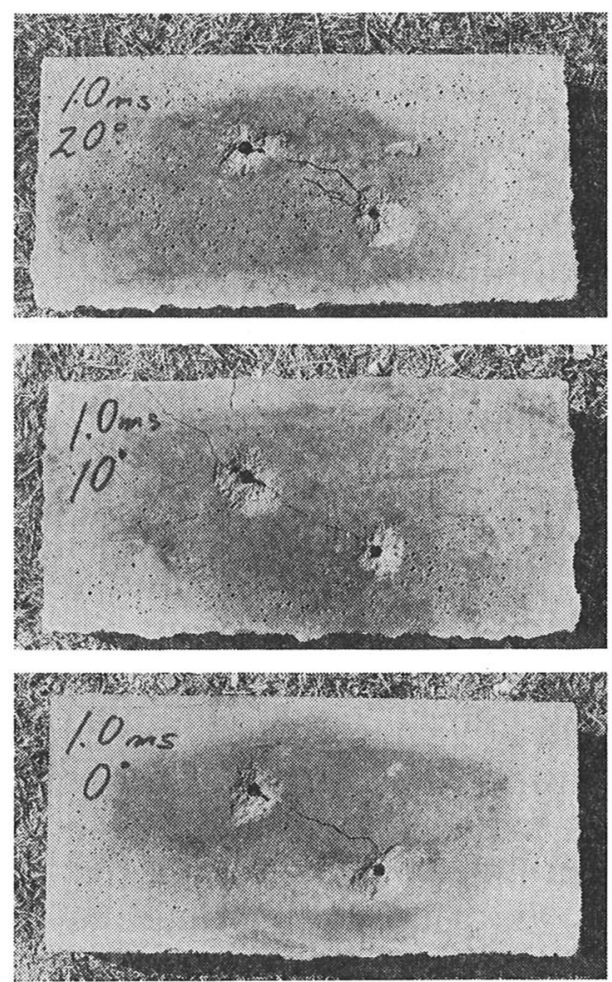

(f) 右下孔爆破後, 左上孔爆破むでの時間差 $1.0 \mathrm{~ms}$ 写真一2 時間差をもつ爆破での両孔間のクラックの連結（切り欠きの傾きは上から $20^{\circ}, 10^{\circ}, 0^{\circ}$ ) 


\section{4. 実験結果と考察}

写真一2 に実験Aの結果の例を示す. 実験はそれぞれ の条件について各 3 個, 合計 54 個の供試体について行 い，写真一2 にはその代表的な結果を示している.

まず切り欠きを有さない孔の爆破は行わず，切り欠き を有する孔のみ爆破した場合, 切り欠きを延長した方向 に卓越したクラックの発達するのがみられた（写真一2 (a)). しかし, その場合表面へ現われてくるクラックは 必ずしも直線状とはいえず，かなりの屈曲を示し，また 隣接する空孔によって影響されるともいえない.

次に切り欠きを有さない孔を先に爆破し，十分な時間 間隔の 後切り欠きを有する孔を爆破する場合（写真一 (b)), まず最初の爆破により爆破孔の周囲にはいくつか のクラックが発生する. そしてこの状態のところへ遅れ て爆破された孔からクラックが進展してくることにな る.このクラックはあらかじめ存在していたクラックと なす角が大きいときに法明瞭な交角をもって交わるよう な形をとるが, 両者のな寸角が小さい場合には後から進 展寸るクラックは前のクラックに引き寄せられるように なり，曲線を描いて両者はつながるようである。これと 同様な傾向は $20 \mathrm{~ms}$ の時間差を扔いて爆破した場合に も認められる (写真一2 (c))。すなわち，これらの時間 差をおいた爆破の場合には最初の爆破孔からのクラック の発生法その後の爆破には無関係であり，孔から放射状 にある角度間隔をもって数本のクラックを発生させる. そこへ切り欠きを延長するクラックが進展してくると き，このクラックに近い位置に先のクラックが存在する とこのクラックは先のクラックと合流し, 爆破孔の連結 が行われることになるのであろう。

次に，両爆破孔の爆破を同時に行うとき，両孔からの 衝撃波は波頭部分を含めて両孔間で重㸚わせられ，両 孔間を結ぶ面の近くでは引張応力域が形成される．たと えば 同時爆破の場合の切り久きの傾き $10^{\circ}, 20^{\circ}$ の例を みると, クラックの発生位置は必ずしも爆破孔周縁とは 限らず，両孔の中閒でも発生しているようにもみられる (写真一2 (d)). そして, この場合には両孔を結ぶ面の 近くでの引張応力の発生，あるいはそれに伴らクラック の発達が著しくなるため, 爆破孔につけられた切り欠き 方向が爆破孔間を結ぶ方向と一致しない場合にはクラッ クの発達方向を制御する目的からは効果が小さく，切り 欠き先端からのその方向へのクラックの発達は小さいか あるいは切り欠き先端ともう一つの爆破孔とを結ぶ面に 沿った破壞が生じる．しかるに切り欠き方向が孔間を結 ぶ面と一致する場合には両孔間を結ぶ面上のクラックは 著しく発達し, しかもそのクラックはほとんど直線状と
なる。

両孔の爆破時間差が $0.5 \mathrm{~ms}, 1.0 \mathrm{~ms}$ の場合 (写真一 2 (e)，(f)）を考える. 爆破後 0.5 あるいは $1.0 \mathrm{~ms}$ で は衝撃波波頭部分はおよそ $2 \sim 4 \mathrm{~m}$ の距離を伝播し，か なり減衰しているのであろう。そして衝撃波に続く準静 的なガス圧がこれらの時間を経過した後で孔壁にどの程 度作用しているかは不明である。しかし侍間差 $20 \mathrm{~ms}$ の場合と比べてクラックの発達機構に明確な差があるた めかなりの圧力が作用しているものと考える。これらの 時間差（時間差 $0.5 \mathrm{~ms}, 1.0 \mathrm{~ms}$ ) で特徵的なことは両孔 間を結ぶようなクラックが大きくない間隔で 2 本形成さ れる可能性が高いことである．実際にこれらの時間差で 切り欠きの傾きが $10^{\circ}$ および $20^{\circ}$ の供試体に限ってみる と全 12 個の 5 6 個についてこの傾向が明らかであっ た. この状況は最初の爆破孔からのクラックがまだ十分 に発達しない間に隣接孔の爆破が行われるため，孔間を つなぐ方向でのクラックの選択的発達が生じ, また切り 欠きからのクラックの成長も最初の孔の応力場の影響を 受けつつ成長するため 2 本のクラックが発達する結果に なると考穴られよう。

次に，実験 Bの結果の例を写真一 3 亿示寸．実験はそ れぞれ同一の条件に対して 2 3 個を行っており，供試 体個数は合計 77 個である. 爆破はまず左側の孔から行 い，続いて所定の時間間隔後右側の孔で行っている.

両孔の爆破が十分な時間差をもって行われる場合（写 真-3 (a)), $S$ (Space : 孔間隔) $=8 \mathrm{~cm}, 12 \mathrm{~cm}$ について はほぼ両孔を結ぶ平面に近い壁面が形成されるが $S=16$ $\mathrm{cm}$ に対してはクラックの発達はそれぞれ独立に生じた と考えてよく, 前に発達していたクラックに後発のクラ ックの成長がしゃ断された状態となっている．また $S=$ $25 \mathrm{~cm}$ ではたまたま後発のクラックが先発のクラックの 近くに発達したため, 誘引されて連結されたものと解釈 されよう。このように爆破に十分な時間間隔がありかつ 爆破孔間の距離が大きい場合には壁面の形成は 2 つの孔 から任意の方向に発達するクラックの成長の結果として の偶然性を有すると考えられる。しかしながら $S=8 \mathrm{~cm}$ および $12 \mathrm{~cm}$ の場合には壁面は自由面に対して顕著に 平行に近くなる.これは右側の孔のみ両側に自由面に平 行な長いクラックを有することから前述伊藤らの説に従 って解釈される，すなわち左孔の爆破による衝撃波によ って右孔には両孔を結ぶ方向の直径の両端に自由面に平 行なクラックが発生し, 続いて行われるクラックを有す る孔の爆破によって著しくこのクラックが発達し, 壁面

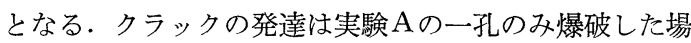
合にみられるように単一の孔の爆破のみでは著しくはな く, 第 2 の孔の爆破によって発達した面が著しく支配的 となる.このことから伊藤らの解釈はこの実験において 

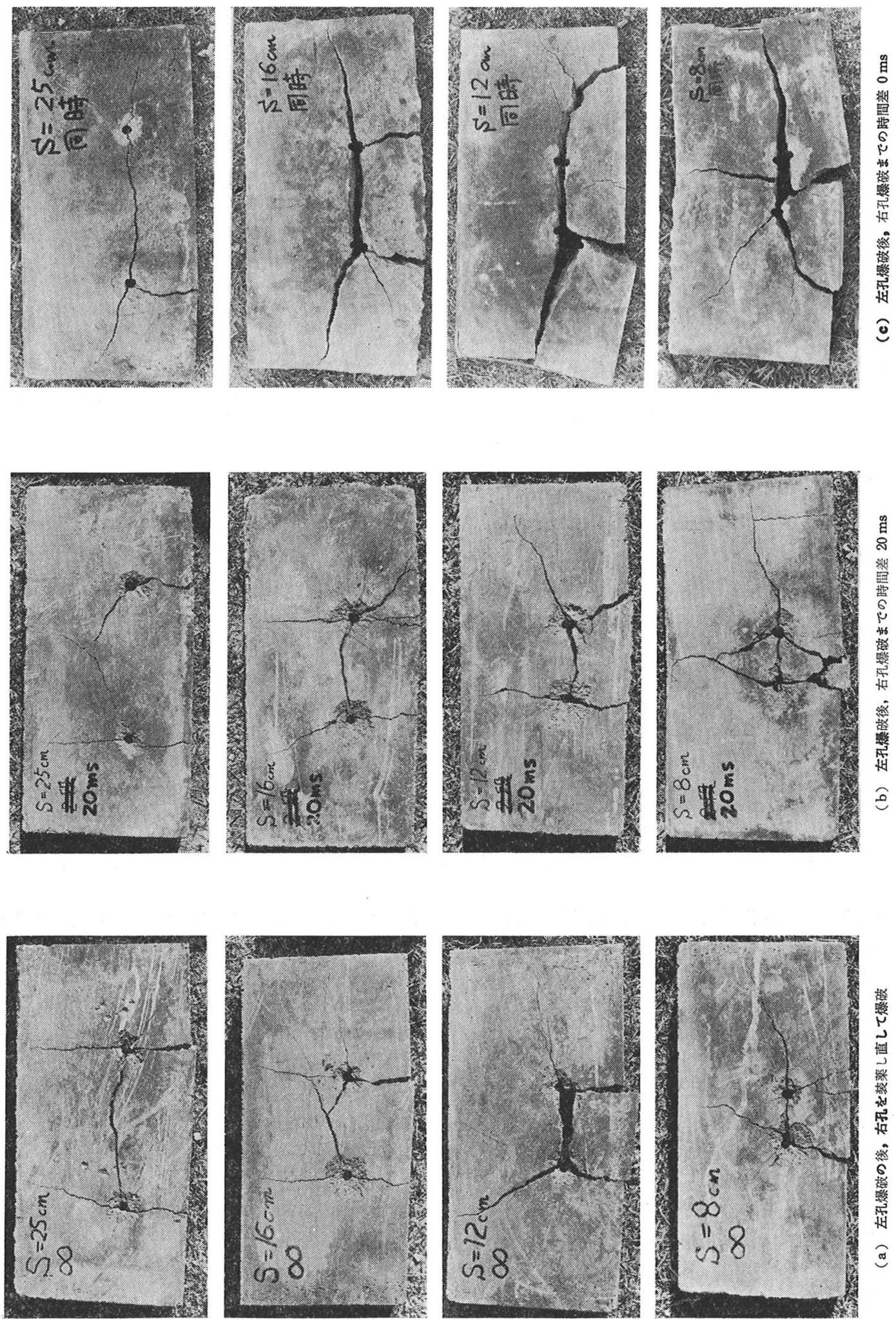

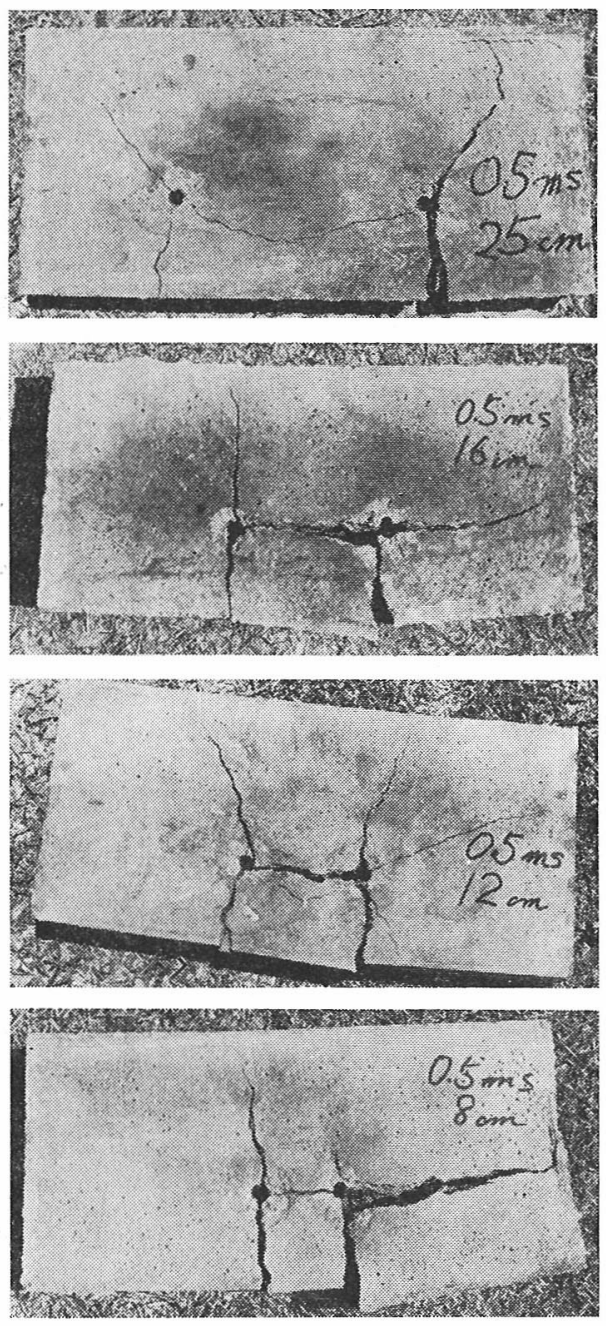

(d) 左孔爆破後, 右孔爆破むでの時間差 $0.5 \mathrm{~ms}$
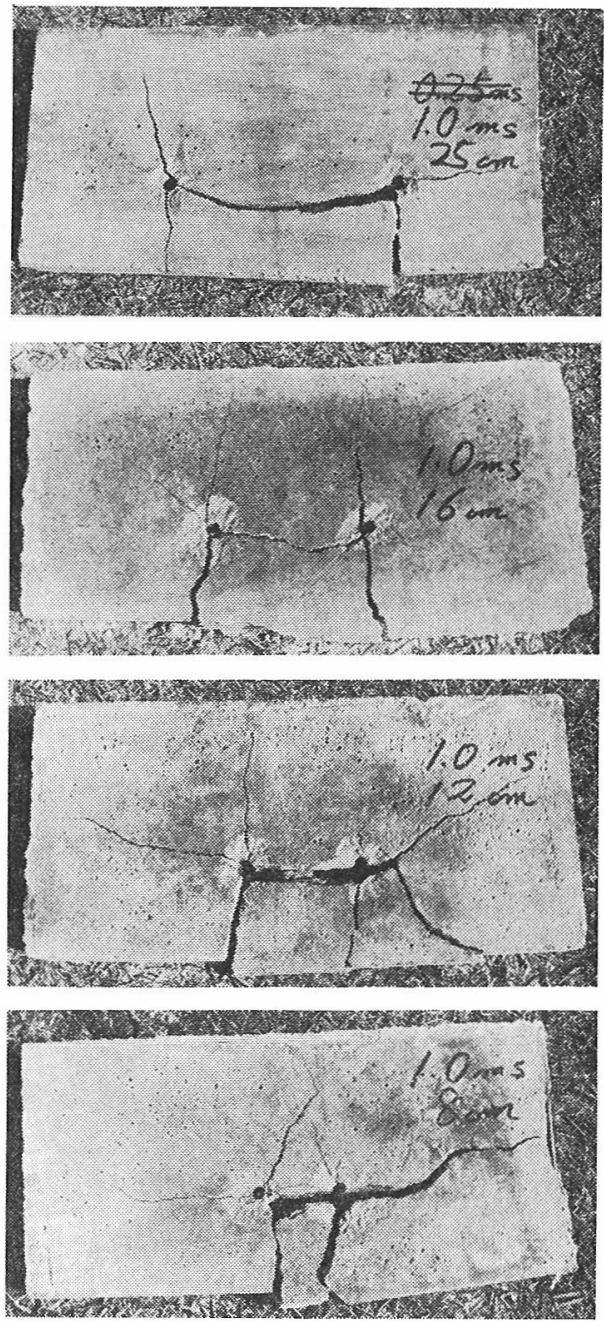

(e) 左孔爆破後, 右孔爆破までの時間差 $1.0 \mathrm{~ms}$

写真一3 時間差をもつ爆破での壁面の形状（孔間隔は上加ら $25 \mathrm{~cm}, 16 \mathrm{~cm}, 12 \mathrm{~cm}, 8 \mathrm{~cm}$, 最小抵抗線距離 $10 \mathrm{~cm}$ )

孔間隔が $12 \mathrm{~cm}$ 以下の場合に有効であるといえる.

爆破時間差が $20 \mathrm{~ms}$ の場合 (写真一3 (b)) にも先と ほぼ同様な傾向がみられる.この場合にも左孔の爆破に よる右孔のクラックの発生の結果と思われる破壊は $S=$ $8 \mathrm{~cm}, 12 \mathrm{~cm}$ について認められる.

これと比べて左右両孔を同時に爆破する場合（写真一 3 (c))には少なくとも $S$ が $16 \mathrm{~cm}$ 以下の場合両孔間の 破壞は雨孔を結ぶ平面近くに集中されるようである. そ して $S=8 \mathrm{~cm}$ の場合を除いては供試体の地山側一伸展 するクラックはほとんどみられない。このことは前述の クラックの発達が相互の衝撃波（実際には爆轟衝撃波） の重ね合わせおよびそれに続くガス圧による応力場の影 響を受けて両孔を結ぶ面近くに集中し，エネルギーがこ の部分の破壊に多く消費され，それ以外の方向のクラッ クの発達が著しく抑えられ，また同時に相互の孔からの
衝撃波が孔間を結ぶ方向以外のクラックの発達を抑える ためであると解釈される． $S=25 \mathrm{~cm}$ となるとこの直線 性は若干失われるが，それでもかなり平面に近い壁面が 形成されるとしてよいであるう.

爆破時間差が両者の中間となる $0.5 \mathrm{~ms}, 1.0 \mathrm{~ms}$ の場 合 (写真一3 (d), (e)), 前二者とは異なった状態が生じ る. すなわち爆破孔間隔 $S$ が小さいときには先行する 孔の爆破により右孔にクラックが生じ，そのクラックを 発達させる形で両孔を平面状に結ぶ壁面が形成されるの がよく観察される. しかし $S=25 \mathrm{~cm}$ では両孔を結ぶ壁 面が大きな弧状の曲面となる．この状況については前述 の準静的なガス圧による応力場でのクラックの発達から 解勫されるべきであろう.

これらのクラックの応力場での発達を厳密に考えよう とすれば，供試体端やクラック面での応力波の反射によ 
る応力場の乱れを考慮する必要がある. しかし材料中で の波動の減衰や反射波の複雑な干渉により本研究の目的 とするクラックの発達傾向の評価のためには爆破孔から の直接的な応力場の影響に重きを置いても特に大きな問 題はないであろう。

以上の実験結果を unevenness を用いて図にしたもの が図一3である.ここで壁面の unevenness は供試体の 表面（爆䡛が供試体中へ進入する面）と最終壁面との交 線が表面上で両孔中心を結ぶ直線から最も偏った距離の 絶対值としてとった.この偏りを図のように孔間隔およ び爆破時間差について整理するとそれぞれの爆破時間差 に対しては偏りの分布は孔間隔の増加に伴う広がりをも
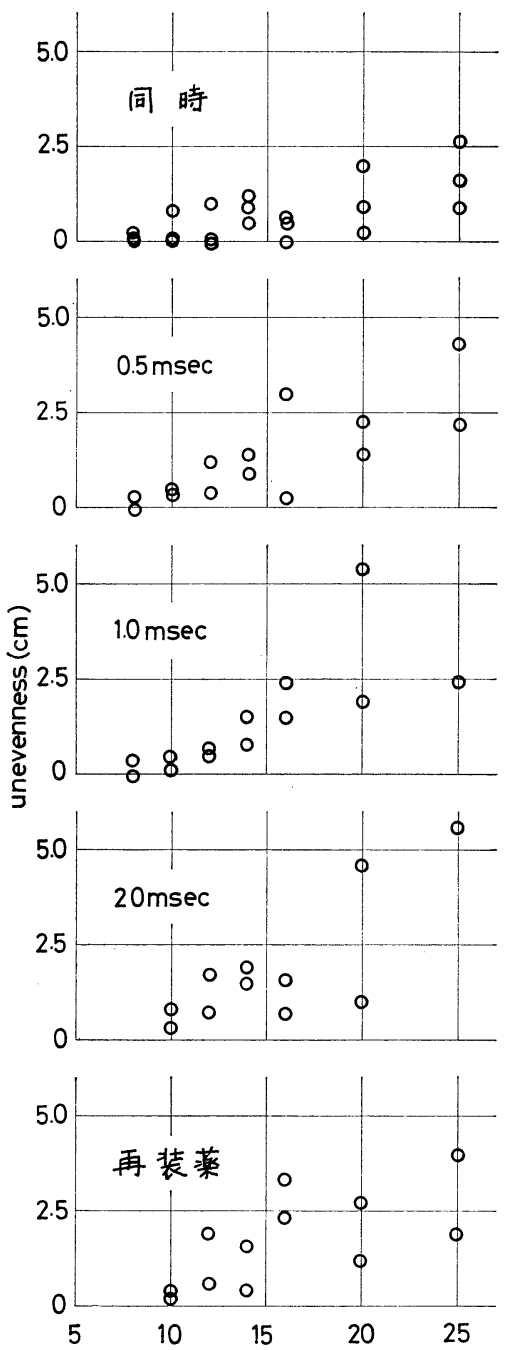

孔 間隔 $(\mathrm{cm})$

(上から時間差 $0,0.5 \mathrm{~ms}, 1.0 \mathrm{~ms}, 2.0 \mathrm{~ms}$ ) 図一3 爆破時間差, 孔間隔による最終壁面の 平面からの偏り (Unevenness)
って広範囲となるようであるそそしてこの場合の広がり を与える勾配は同時爆破の場合が一番小さく，時間差が 大きくなることによって大きくなっていくのが認められ る. このことからみて隣接する孔の爆破の時間差を小さ くすることは効果的な $\mathrm{SB}$ を行うために非常に大切な要 素であると考えられる．またこの偏りを自由面側による ものを負，地山側によるものを正として考えるとき，一 般的にいわれているように孔間隔が小さいとき（過装薬 ぎみ）には偏りは正となり，孔間隔が大きいとき（装薬 量不足）には負となる傾向がある程度みられるよらであ るが必ずしも明確とはいえないようであった。

本実験では実際の SB の条件と比較して供試体の大き さが十分でないため爆破により供試体が部分的に分離, 移動を生じ, 実際の発破においては生じ得ないようなク ラックの発達がみられる. 同時爆破以外の場合, 多くの 供試体に扔いて爆破孔から地山側一伸びるクラックのか なりの部分は供試体の部分的な移動によって大きく発達 したものと考光られ，実際の発破の場合のように両側へ の移動，回転が拘束されておれば爆破孔からの他の放射 状クラックのようにほぼ閉じたような状態にあったと予 想される．このことを考慮に入れるとしても同時爆破の 場合とある時間差をもって爆破した場合の地山側へのク ラックの発達には著しい差が認められる. すなわち隣接 する孔を同時に爆破することにより相互の孔からの衝撃 波は孔間を結ぶ方向以外へのクラックの発達を抑制し， 両孔を結ぶ面に破壊を集中させ，この部分での有効なエ ネルギーの解放を行う，その結果，同時爆破は他の方向 への破壊を著しく軽減させる効果があり，オーバーブレ 一クを減少させるのみならず地山を傷めないためにも有 効な方法であると推察される.

\section{5.おわりに}

以上のように本研究においては SB の機構に関する諸 説を検討, 考察し, 発展解䣋することから始めてそれら の諸説の妥当性をセメントモルタル供試体によるモデル 実験により検討することを目的とした. そのため大別し て 2 種類の供試体を作製し，隣接する 2 つの爆破孔の爆 破時間に差を与え, 爆破孔周辺で破壊開始が生じ, かっ 発達する場合の応力場に差をつけた実験を行った.

実験および考察の結果得られたおもな結論は以下のと おりである。

（1）通常の SB においては衝撃波，ガス圧がそれぞ れ独立にではなく一連のものとして働く.そして隣接す る孔の爆破が行われる時間の差によって SB の機構, 特 に破壊初期の機構における衝撃波の働きに差があると考 えられる。 
（2）隣接する孔が同時に爆破される場合には両孔の 間で衝撃波の波頭の重ね合わせが行われ，またそれに続 くガス圧の影響も重ね合わされる.そのためクラックが 孔周縁のみならず孔と孔とを結ぶ平面近くで発生する可 能性も高くなる．また孔周縁からクラックが発生する場 合にも隣接孔の爆破の影響を大きく受け，両孔を結ぶ面 近くに集中する.さらにこの部分での速やかなエネルギ 一の解放が行われまた隣接孔による応力場は両孔を結ぶ 方向以外のクラックの発達を抑えるため他の方向への破 壊の発達は小さい.

（3）隣接する 2 つの 孔の爆破が $0.5 \mathrm{~ms}$ あるいは $1.0 \mathrm{~ms}$ といら短い時間差をもってなされる場合, 衝撃 波の波頭は両孔間で重なり合らことはない。しかし先に 爆破された孔からみればガス圧の作用により孔周辺のク ラックが発達しつつある間に隣接孔からの衝撃波が到達 し, また後から爆破される孔からみれば先の孔の爆破に 伴うガス圧による応力場で爆破が行われることになる. そのため両孔間のクラックは両孔を結ぶ面近くで選択的 に発達させられる．しかしこの相互作用は同時爆破の場 合に比べて弱い，そのためクラックが両孔を結ぶ面から 若干外れて発生, 発達することもあるが, 孔相互に相手 孔からの応力場の影響を受けるためクラックは滑らかな 弧を描いて両孔をつなぐことになる.

（4）十分な時間差をおいて 2 つの孔が爆破される場 合には相互に及ぼす応力場の影響はない.そのため先に 爆破された孔からのクラックの発生した場へ後から爆破 された孔からのクラックが進入し, 両者が連結されるこ とによって壁面が形成される. そのため最終壁面の形成 は両孔から任意方向に発生, 発達するクラック方向に支
配される. しかし両孔の間隔が小さく, 先行する爆破に よる他の孔周縁での両孔を結ぶ方向でのクラックが発生 寸る場合には, 遅れて行われる爆破によりこのクラック が発達し，比較的平面に近い壁面が形成される. この 状況は前項の時間差 $0.5 \mathrm{~ms}, 1.0 \mathrm{~ms}$ の場合も同様であ る.

（5）同一時間差で爆破が行われる場合には Unevenness は孔間隔の増大に従い増大する．この広がりの 程度は時間差が大きくなるほど大となる傾向を示す。

謝辞：本研究を行うにあたり多くの方々のご援助 をいただいた，特に，実験に便宜をお図りいただいた日 本化薬（株）厚狭工場の石井工場長に感謝する次第であ る.また，実験に協力いただいた日本化薬（株）荒木主 任, 徳山高専 橋本助手をはじめ多数の山口大学の職員, 学生の諸氏に感謝する.

\section{参考 文 献}

1）工業火薬協会 : 発破ハンドブック, 山海堂, 1976.

2）たとえば，下村弥太郎・山口梅太郎：スムーズブラステ イングに関する研究 (第 2 報), 工業火薬協会誌, Vol. 30, No. 2, 1969.

3) Paine, R.S., D.K. Holmes and H.E. Clark : Controlling Overbreak by Presplitting, Proc. Int. Nat. Symp. Mining Research, Univ. of Missouri, USA, Pergamon Press, Vol. 1, 1962.

4）伊藤一郎・佐々宏一：スムーズブラスティングにおける 破壊機構の一考察, 日本鉱業会誌, Vol. 84, No. 964, 1968.

5) Langefors, U. and B. Kihlström: The Modern Technique of Rock Blasting, John Wiley \& Sons Inc., 1979.

(1980.9.22 ·受付) 